\title{
Modeling of non-point source nitrogen pollution from 1979 to 2008 in Jiaodong Peninsula, China
}

\author{
Xiyong Hou, ${ }^{1 *}$ Lanlan Ying, ${ }^{1}$ Yuanyong Chang, ${ }^{1}$ Song S. Qian ${ }^{2}$ and Yong Zhang ${ }^{3}$ \\ ${ }^{1}$ Yantai Institute of Coastal Zone Research (YIC), Chinese Academy of Sciences (CAS), 264003, ChunHui Road 17\#, Laishan District, Yantai, \\ Shandong, P.R. China \\ ${ }^{2}$ Department of Environmental Sciences, University of Toledo, Toledo, $\mathrm{OH}$, USA \\ ${ }^{3}$ Shandong Provincial Land Surveying and Planning Institute, P.R. China
}

\begin{abstract}
:
Efforts to reduce land-based non-point source (NPS) pollutions from watersheds to coastal waters are ongoing all around the world. In this study, annual yield of NPS nitrogen (NPS-N) pollution in Jiaodong Peninsula, China from 1979 to 2008 was estimated. The results showed that: from 1979 to 2008, NPS-N yields exhibited significant inter-annual variations and an increasing trend on decadal scale. High NPS-N yield was mainly found in east and south parts, as well as the urbanized coastal regions in Jiaodong Peninsula. Among the 32 river basins, the three largest basins yielded more than $41.16 \%$ of the NPS-N. However, some small coastal watersheds along the South Yellow Sea and Jiaozhou Bay had higher per unit area yield. Most of the small watersheds characterized by seasonal runoff had coastal waters pertain to mild and moderate pollution levels. The ratio of watershed area to shoreline length and the up-stream land use had significant impacts on NPS-N flux through the shoreline. Among the four adjacent coastal areas of Jiaodong Peninsula, Jiaozhou Bay was the most noteworthy one not only because of high levels of land-based NPS-N pollution but also because of its nearly enclosed structure. The combination between integrated coastal zone management and integrated river basin management, land use planning and landscape designing in Jiaodong Peninsula is recommended. Copyright (C) 2013 John Wiley \& Sons, Ltd.
\end{abstract}

KEY WORDS coastal environment; Jiaodong Peninsula; watershed; land use; nitrogen; non-point source pollution

Received 12 December 2012; Accepted 29 April 2013

\section{INTRODUCTION}

Non-point source (NPS) pollution usually refers to pollutions that come from diffuse runoff moving over and through land surface, picking up and carrying various natural or anthropogenic pollutants and finally depositing them into receiving waters (Nikolaidis et al., 1998; Shen et al., 2012). NPS pollution is diffuse in character and plays an important role in water quality degradation; therefore, it has become an active subject of water environment research since 1970s partly because of the eutrophication 'crisis' of the Great Lakes in North America and the promulgation of the Clean Water Act in the USA. In the past three decades, more and more literatures that talked about NPS pollution at local, regional, national and global scales have emerged (Schreiber et al., 2001; Norse, 2005; Ulen et al., 2007; Yuan et al., 2007; Dowd et al., 2008; Lee et al., 2009;

\footnotetext{
*Correspondence to: Xiyong Hou, Yantai Institute of Coastal Zone Research (YIC), Chinese Academy of Sciences (CAS), 264003, ChunHui Road 17\#, Laishan District, Yantai, Shandong, P.R. China.

E-mail: xyhou@yic.ac.cn
}

Badruzzaman et al., 2012). In China, the rapid socialeconomic development since the late 1970s has contributed to serious NPS pollution, and hence studies on NPS pollution have gradually attracted attentions in the past three decades. Earlier researches on NPS pollution in China in late 1980s were mainly focused on urban runoff pollution in Beijing and some important water bodies such as Dianchi and Taihu Lake (Guo et al., 2004; Kuang et al., 2004; Ongley et al., 2010). The main progress had been made in this period was the recognition of the problems and preliminary understandings on mechanisms and characteristics of NPS pollution. Among the following studies, a great deal of efforts have been put on agricultural NPS pollution because China is one of the largest producers and consumers of chemical fertilizers and pesticides in the world, and the excessive nutrient loads from agricultural watersheds has been considered as the primary source of NPS pollution (Chen et al., 2011; Shen et al., 2012; Wu et al., 2012). Specifically, nutrients from excessive fertilizer utilization and pesticide spraying were deposited into rivers, lakes and reservoirs, resulting in deterioration of water quality, eutrophication and reduction of biodiversity in the 
aquatic ecosystems (Maxted et al., 2009; Meixler and Bain, 2010; Yen et al., 2012).

Land-based pollution, especially NPS pollution that is closely related, with land use changes, is becoming a hotspot of multi-disciplinary research in coastal zone throughout the world (Nikolaidis et al., 1998; Blanco et al., 2010; Xu et al., 2012). As a matter of fact, landbased NPS pollution has become the fundamental reason of coastal water degradation in many places, which boosts phytoplankton biomass, reduces water clarity, increases frequency of toxic algae blooms and aggravates risks in coastal zone (Goolsby and Battaglin, 2001; Bradley and David, 2003; Islam and Tanaka, 2004; Houk et al., 2005; Wit et al., 2005; Selig et al., 2006; Howarth, 2008; Rollo and Robin, 2010; Nagy et al., 2012; Williams et al., 2012). For recent years, very extensive land use changes have happened in China. As a result, excessive nutrients and heavy metals closely related with NPSs have led to serious pollution and algae blooms, and disturbed wetland hydrology in both inland and coastal waters (Guo et al., 2004; Li et al., 2009a; Ongley et al., 2010; Xu et al., 2012). With the abatement of point source pollution, NPS pollution has become an increasingly important environmental concern of aquatic ecosystem and human beings (Shamshad et al., 2008; Ma et al., 2011; Miller et al., 2011). Efforts to reduce NPS pollutants loadings from watersheds to coastal waters have been ongoing for a long time in the developed countries (Pierobon et al., 2012). However, up to now, limited studies have been found with a focus on land-based NPS pollution in China's coastal zone (Yuan et al., 2007; Huang and Hong, 2010; Chen et al., 2011), and thereby, knowledge about this issue is lagging far behind that has been achieved in inland water bodies in China.

Jiaodong Peninsula, as the largest peninsula in China, has experienced rapid population growth, social and economic development, and dramatic land use and land cover changes in the past three decades. As a result, nutrient over-enrichment and serious environmental problems caused by increased point source and NPS pollution have been found in inland and coastal waters of Jiaodong Peninsula (Wei et al., 2008), such as repeated red tide outbreaks offshore of Yantai city from 2004 to 2009 (Hao et al., 2011). However, present studies in this region mainly put emphasis on estuary nutrient flux and its environmental impacts on a number of critical areas of coastal water for short time periods (Liu et al., 2007; Zhang, 2007; Liu et al., 2010; Han et al., 2011). Longterm characteristics of NPS pollution and its impacts on coastal water are scarcely talked about, which restricted our deep understanding of the land-ocean interactions in coastal zone (LOICZ) and the effective implementation of the integrated coastal zone management (ICZM) in Jiaodong Peninsula.
In this study, by taking NPS nitrogen (NPS-N) pollution as an example, the primary objectives are the spatial-temporal characteristics of long-term NPS-N yield in land area and the spatial patterns of land-based NPS-N pollution risks at estuaries that have permanent runoff and shoreline segments that have storm water runoff only in Jiaodong Peninsula. In specific, we establish a multifactor database and develop evaluation models in GIS to estimate the long-term NPS-N pollution and to assess the risks of land-based NPS-N pollution in coastal waters in Jiaodong Peninsula. The section 'Materials and methods' briefly introduces the Jiaodong Peninsula and then describes the datasets and methods used to evaluate long-term characteristics of NPS-N pollution. The section 'Results and discussion' includes the spatiotemporal variations of NPS-N yield, NPS-N fluxes from land to coastal waters through estuaries and shoreline segments, and levels of land-based NPS-N pollution in coastal waters. The last section is the 'Conclusion'.

\section{MATERIALS AND METHODS}

\section{Study area}

Jiaodong Peninsula usually refers to the spatial area that lies the east of Jiaolai River in Shandong province, China. It locates between $35.8-38.0^{\circ} \mathrm{N}$ and $119.8-122.9^{\circ}$ E, facing Bohai Sea to the northwest and Yellow Sea to the south and northeast. In this paper, based on the shuttle radar topography mission digital elevation model (SRTM DEM), the study area is redefined to the spatial domain of river basins (Figure 1) delineated by hydro-analysis techniques in ArcGIS 9.3, which has very limited difference with Jiaodong Peninsula in the usual sense. In specific, three big river basins that have perennial river runoff had been delineated, which are Dagu River basin, Wulong River basin and Dagujia River basin. In addition, 29 small watersheds, which are mostly seasonal rivers that have storm water runoff only in recent decades, had been delineated also. As the largest peninsula in China, Jiaodong Peninsula covers cities of Yantai and Weihai and most part of Qingdao, with an area about $28230 \mathrm{~km}^{2}$. It is characterized by warm-temperate humid monsoon climate, with the highest average monthly temperature of $25^{\circ} \mathrm{C}$ in July and the lowest monthly average temperature of -3 to $-1{ }^{\circ} \mathrm{C}$ in January. The average annual precipitation ranges from 650 to $850 \mathrm{~mm}$ in different parts of the peninsula. Agriculture land is the main land use type, which accounts for more than $57.30 \%$ of the whole peninsula; the following is grassland, which accounts for $14.80 \%$; and the third is forest, which accounts for $11.45 \%$; urban area, rural settlement and independent industrial-mining area account for $13.40 \%$ in total, and the rest of the land are inland water body and unused land, which accounts for 


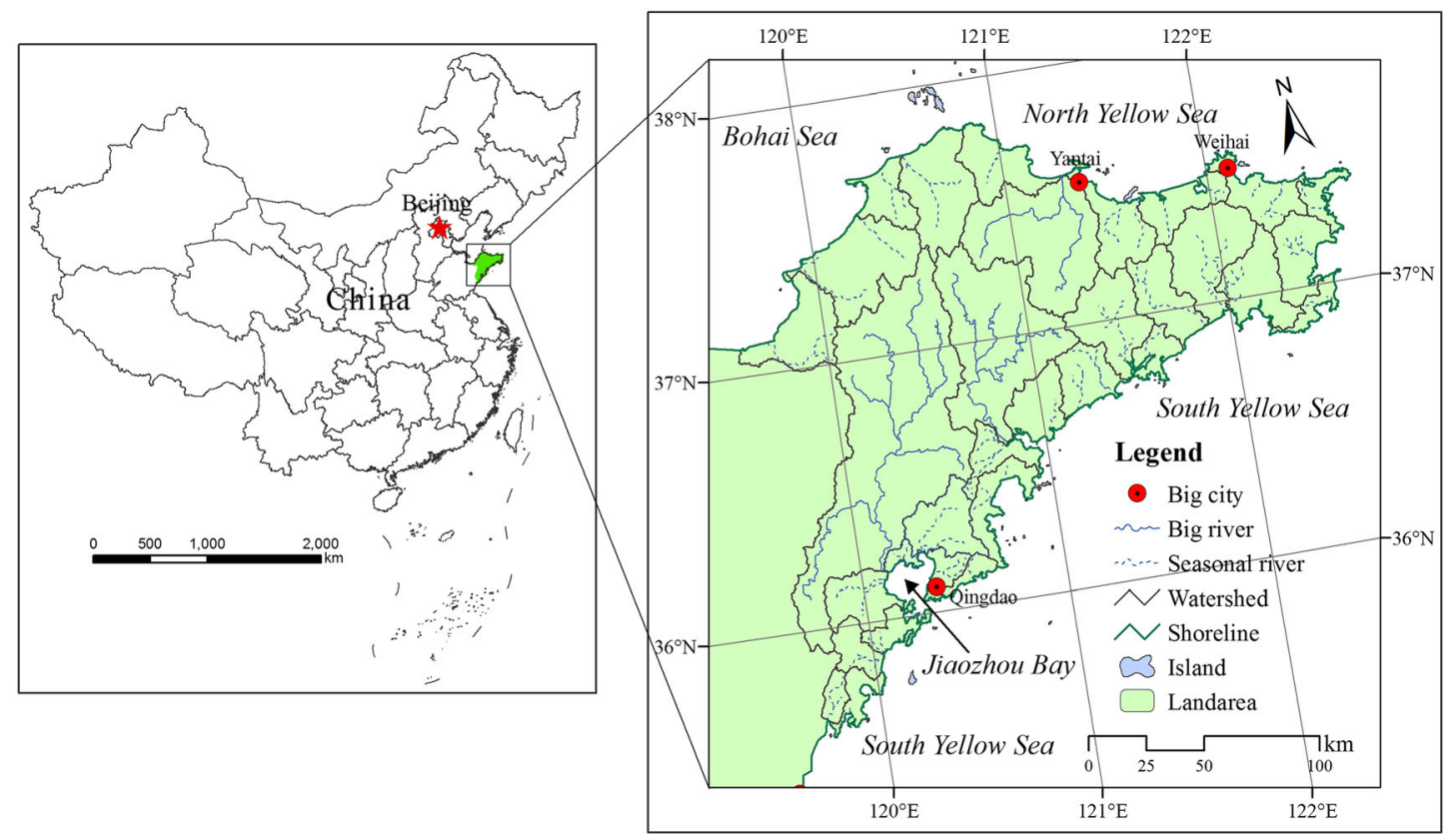

Figure 1. Location map of the study area and major rivers

$3.05 \%$ in total. Both rapid urbanization and intensive coastal zone development have resulted in remarkable land use and land cover changes in the past 30 years, among which urban expansion and sea reclamation are the two most significant characteristics.

\section{Data}

A multi-source spatial database was prepared, including remote sensing images and land use maps in multiple years, DEM, soil maps and soil survey data, precipitation data of meteorological stations, and runoff data of hydrological stations, pollutant coefficients and a variety of ancillary data. Essential data and fundamental processing are as follows.

Predominantly cloud-free images of Landsat MSS/TM/ ETM + that captured in 1979, 1990, 1995, 2000 and 2005, respectively, were acquired mainly from USGS EROS Data Center (http://eros.usgs.gov/) and GLCF Data Center (http:// glcf.umiacs.umd. edu/). Multi-period land use maps were created by the visual interpretation method based on these images, photos and GPS data collected during field surveys, and a variety of ancillary data, such as topographical maps, existing land use/cover maps, road network maps, river maps, settlement maps and so on. The hierarchy of land use was established based on image capabilities, research goals and regional land use characters, which include agriculture (AGRL), forest (FRST), grass/pasture (PAST), water body (WATR), urban (URAN), rural settlement (RURL) and independent industrial-mining (INDL).

The DEM data was downloaded from the SRTM $90 \mathrm{~m}$ digital elevation database distributed by the GLCF Data Center (http://glcf.umiacs.umd.edu/). DEM data was used to delineate watersheds, extract river networks and calculate surface flow variables by using the spatial analysis techniques and hydrological analysis tools in ArcGIS 9.3. Overall, 32 watersheds were delineated, among which there are three largest watersheds with permanent rivers flow into coastal waters, and other 29 small coastal watersheds with mostly seasonal rivers in recent decades.

Precipitation is the fundamental source of surface runoff and main impetus for NPS pollutant transportation. Monthly precipitation data from 1979 to 2008 at 15 meteorological stations were available from the China Meteorological Data Sharing Service System provided by the Chinese Meteorological Administration. Annual precipitation series were first synthesized, and then, station-gauged series were expanded into gridded spatial data by Kriging method in ArcGIS 9.3.

The annual runoff data from 1972 to 1985 were collected from five hydrologic stations (Tuanwang (S1), Menlou (S2), Fushan (S3), Muyu (S4) and Mishan (S5)), which are distributed evenly in the study area. Runoff data was used to calibrate and validate the Soil Conservation Service Curve Number (SCS-CN) model.

Soil data were extracted from the 1:500000 soil maps and soil-profile property data of Shandong Province, China. The data were generated during the Second Soil Survey in the mid 1980s. According to the guidelines of the SCS-CN model, soils were classified into hydrologic soil groups (HSGs) to determine runoff $\mathrm{CN}$ (Shamshad et al., 2008). Specifically, the HSGs, which are A, B, C and $\mathrm{D}$ assigned to each soil type, are elements used in defining the minimum rate of infiltration. From A to D, 
soils have high, moderate, slow and very slow infiltration rates, respectively, even when thoroughly wetted (Table I).

\section{Methods}

SCS-CN method was used at $100 \mathrm{~m}$ spatial scale to simulate surface runoff, and the pollutant coefficients are combined to quantify NPS-N yields.

Surface runoff yield can be estimated by the SCS-CN method which is a widely used empirical model developed by the U.S. Department of Agriculture Natural Resources Conservation Service. A $\mathrm{CN}$ is assigned primarily based on soil permeability. $\mathrm{CN}$ is used to calculate the potential maximum retention $\mathrm{S}$ (Equation (1)), and then, runoff is calculated by combining $S$ and precipitation (Mishra et al., 2006; Xiao et al., 2011):

$$
\begin{gathered}
S_{i}=254\left(\frac{100}{C N_{i}}-1\right) \\
Q=\left\{\begin{array}{cr}
(P-0.2 S)^{2} /{ }_{(P+0.8 S)} & P \geq 0.2 S \\
0 & P<0.2 S
\end{array}\right.
\end{gathered}
$$

where $C N_{i}$ is a given $C N$ value and $S_{i}$ is the corresponding potential maximum retention $(\mathrm{mm}), P$ is the rainfall (mm), $Q$ is the runoff quantity ( $\mathrm{mm}$ ) and $S$ is the potential maximum retention $(\mathrm{mm})$.

The initial $\mathrm{CN}$ values of agriculture land, forest and grass/pasture were cited from a literature (Zou et al., 2008) by which the SCS-CN model was developed for a small sub-basin of Dagu watershed in Jiaodong Peninsula. However, the study area of the article failed to cover the other kind of land use; therefore, two more literatures were cited (Huang et al., 2005; Xiao et al., 2011) to obtain the initial $\mathrm{CN}$ values of the other kind of land use.

Pollutant coefficients represent the concentration of a specific pollutant in runoff coming from a particular land use type within a watershed. Pollutant coefficients are reported as a mass of pollutant per unit volume of water $\left(\mathrm{mg}^{-1}\right)$. In this study, an intensive literature review (Ying et al., 2010) and an in-depth comparison between Jiaodong Peninsula and four hotspot areas of China, including Miyun reservoir

Table I. Hydrological soil groups in Jiaodong Peninsula

\begin{tabular}{lll}
\hline $\begin{array}{l}\text { Hydrological } \\
\text { soil groups }\end{array}$ & \multicolumn{1}{c}{ Soil texture } & $\begin{array}{c}\text { Infiltration } \\
\text { rates }\end{array}$ \\
\hline A & Sand, sandy loam & High \\
B & Silt loam, loam & Moderate \\
C & Sandy clam loam & Slow \\
D & $\begin{array}{l}\text { Clay loam, silty clay, } \\
\text { sandy clay, clay }\end{array}$ & Very slow \\
& & \\
\hline
\end{tabular}

basin (Bao et al., 1997; Wang et al., 2002, 2003, 2004), Taihu lake basin (Li et al., 2004, 2006a, b, c; Li et al., 2007, 2009a, 2009b), Upper-middle Yangtze River basin (Liang et al., 2007; Long et al., 2008; Liu et al., 2009) and Jiulong River basin (Huang et al., 2004, 2005), had been carried out. The comparability in terms of geographical locations, climate conditions, topographic characters, vegetation, soil, land use and so on (Table II) were analyzed in order to pick out coefficients suitable for Jiaodong Peninsula. The coefficients of nitrogen pollutant for agriculture land, forest, grass/pasture, urban area, rural settlement and independent industrial-mining land in this study are selected as 3.95, $3.09,2.91,3.22,3.58$ and $1.26 \mathrm{mg} .1^{-1}$, respectively.

\section{Calibration and validation}

Surface runoff is the elementary factor to determine the transport of NPS pollutants. Therefore, it is important to calibrate and validate the SCS-CN model based on runoff records of hydrological stations. In detail, the trials and errors method is adopted to calibrate and validate the SCS-CN model until acceptable results are obtained. The assessing indicators of the closeness of the predicted to the observed values include coefficient of determination $\left(\mathrm{R}^{2}\right)$, relative error (RE) and Nash-Sutcliffe efficiency (NSE). $\mathrm{R}^{2}$ refers to the degree of consistency between the simulated and the observed data and shows the proportion of the variance in observed data explained by the model. It varies from zero to one with higher values indicating higher consistency, and generally, values greater than 0.5 are acceptable (Santhi et al., 2001; Van Liew et al., 2003). RE describes the bias of the model and proves better modeling performance if it is close to zero. NSE is a statistical indicator that determines the relative magnitude of the residual variance compared to the observed data variance (Nash and Sutcliffe, 1970). It shows how well the plot of simulated data versus observed fits the 1:1 line. It ranges from $(-\infty$ to 1 ] with low values indicating high deviations between observed and simulated data. If the measured variable is predicted exactly for all observations, the NSE is 1. Negative NSE indicates unacceptable model performance. NSE and RE are defined as follows:

$$
\begin{gathered}
N S E=1-\left[\frac{\sum_{i=1}^{n}\left(Y_{i}^{\text {obs }}-Y_{i}^{\text {sim }}\right)^{2}}{\sum_{i=1}^{n}\left(Y_{i}^{\text {obs }}-Y_{i}^{\text {mean }}\right)^{2}}\right] \\
R E=\frac{\left(V-V^{\prime}\right)}{V^{\prime}} \times 100 \%
\end{gathered}
$$

where $Y_{i}^{\text {obs }}$ and $Y_{i}^{\text {sim }}$ are the $i$ th observed and simulated value for the constituent being evaluated, respectively, 
X. HOU ET AL.

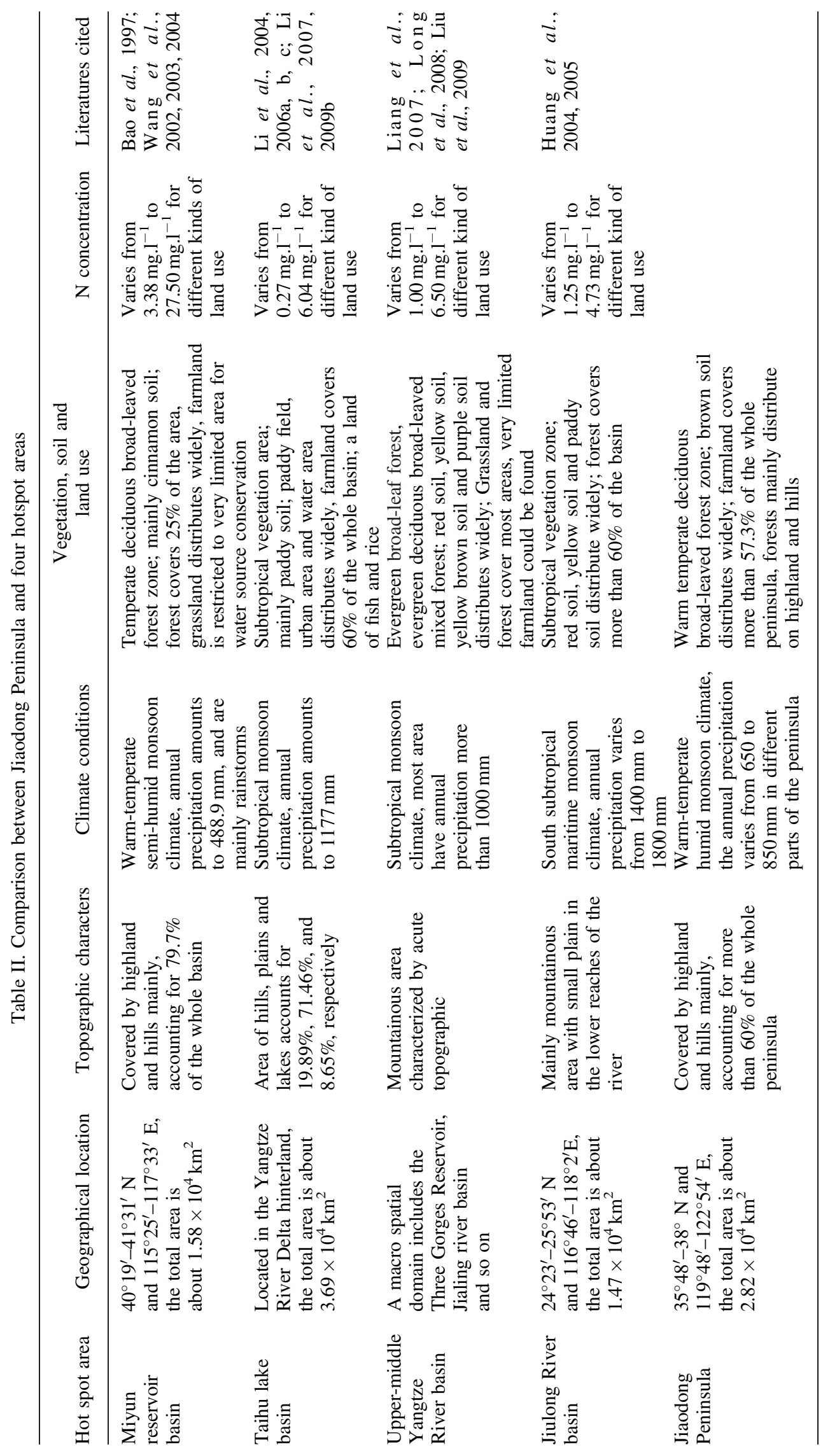


$Y_{i}^{\text {mean }}$ is the mean value of observed data and $n$ is the total number of observation; $V$ is the simulated values, while $V^{\prime}$ is the corresponding observed values.

Observed runoff records from 1972 to 1985 were split into two groups, 1972-1981 and 1982-1985 for calibration and validation purpose, respectively. In specific, parameters in SCS-CN model were calibrated based on the observed surface runoff at five hydrological stations from 1972 to 1981. Calibration was carried out through repeated trials and errors method until satisfactory results were obtained. Afterwards, the calibrated model was verified to estimate annual surface runoff from 1982 to 1985 .

\section{RESULTS AND DISCUSSION}

\section{Validation of the surface runoff estimation}

$\mathrm{CN}$ values are the most important parameters of SCS model; after a lot of trials and errors, the acceptable SCS-CN model has been obtained, in which the final $\mathrm{CN}$ values accepted for Jiaodong Peninsula are shown in Table III. The estimated runoff by SCS-CN model versus the observed runoff of the two time segments was presented in Figure 2, and three variables for the measurement of the closeness between them were shown in Table IV. The $R^{2}$ reached 0.89 and 0.77 in the calibration period and the validation period, respectively, which were far beyond the acceptable levels. The values of RE were much lower in two periods, which shows that the bias of the model were lower. The NSE reached to 0.86 and 0.69 in the two periods, respectively, which further confirmed that acceptable performance had been achieved by the model, according to Moriasi et al. (2007).

The observed data of nitrogen is unavailable. However, we compared our result with the simulated result by Zou et al. (2008) who developed the AnnAGNPS model to simulate the NPS pollution in upper-middle part of Dagu river basin, the largest river basin in Jiaodong Peninsula. The simulated yield of NPS-N from 2000 to 2001 was demonstrated as $10.48 \mathrm{~kg} \cdot \mathrm{hm}^{-2} \cdot \mathrm{a}^{-1}$ by Zou et al. (2008),

Table III. Final curve number assigned for Jiaodong Peninsula

\begin{tabular}{lcccc}
\hline & \multicolumn{4}{c}{ Hydrological soil group } \\
\cline { 2 - 5 } Land use & A & B & C & D \\
\hline Agricultural & 60 & 72 & 79 & 87 \\
Forest & 30 & 55 & 67 & 77 \\
Grass/Pasture & 30 & 48 & 60 & 71 \\
Urban & 89 & 92 & 94 & 95 \\
Rural settlement & 59 & 74 & 82 & 86 \\
Independent industrial-mining & 81 & 88 & 91 & 93 \\
\hline
\end{tabular}

Copyright $@ 2013$ John Wiley \& Sons, Ltd.

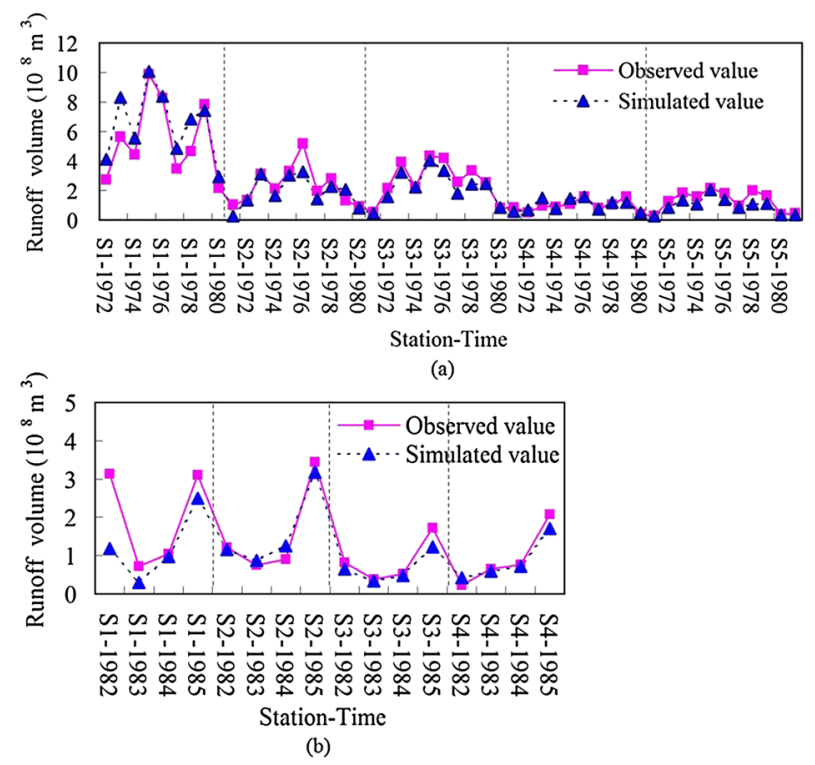

Figure 2. Comparisons of observed and simulated surface runoff for calibration period (a) and validation period (b)

Table IV. Statistical parameters of the surface runoff modeling

\begin{tabular}{lccc}
\hline & $\mathrm{R}^{2}$ & $\mathrm{RE}$ & $\mathrm{NSE}$ \\
\hline Calibration period (1972-1981) & 0.89 & $22.96 \%$ & 0.86 \\
Validation period (1982-1985) & 0.77 & $25.08 \%$ & 0.69
\end{tabular}

and our estimated result $\left(10.18 \mathrm{~kg} \cdot \mathrm{hm}^{-2} \cdot \mathrm{a}^{-1}\right)$ was similar with it, which indicated that both the calibrated SCS-CN model and the pollutant coefficients are acceptable for NPS-N pollution simulation.

\section{Temporal variations of NPS- $N$ yield}

The annual NPS-N yield in Jiaodong Peninsula from 1979 to 2008 exhibited sharp inter-annual variations (Figure 3-a). It varied from $7.81 \times 10^{6} \mathrm{~kg} \cdot \mathrm{a}^{-1}$ in 1981 to $51.30 \times 10^{6} \mathrm{~kg} \cdot \mathrm{a}^{-1}$ in 2007 , with average annual value of $20.35 \times 10^{6} \mathrm{~kg} \cdot \mathrm{a}^{-1}$. A decadal increasing trend was apparent when dividing the time period into three 10-year periods (Table V). The increases of fertilizer use and poultry farm, as well as the intensification of human activities, are the fundamental reasons of the overall increasing trend of NPS-N yield.

Dagu watershed, Wulong watershed and Dagujia watershed are the three largest watersheds in Jiaodong Peninsula. They have long rivers, large spatial domain, perennial runoff regimes, and overall, they dominate the primary spatial-temporal characters of the annual NPS-N yield in the whole peninsula. The estimated NPS-N yield from 1979 to 2008 in the three watersheds also showed significant inter-annual fluctuations (Figure 3-b). Dagu 


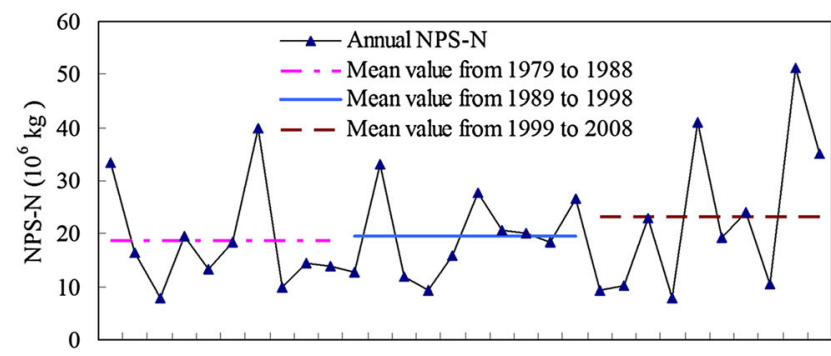

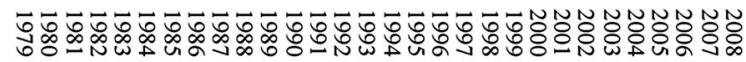

Year

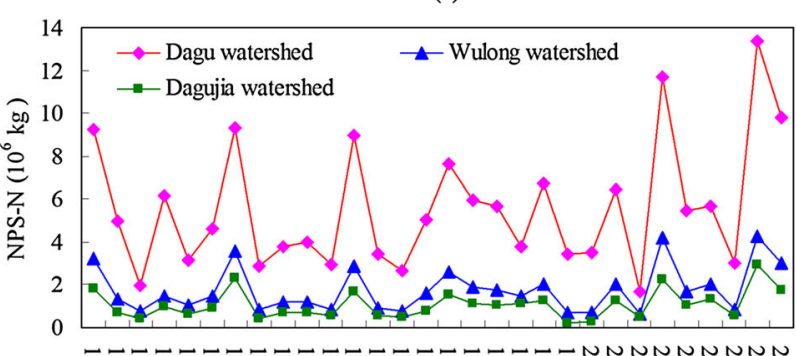

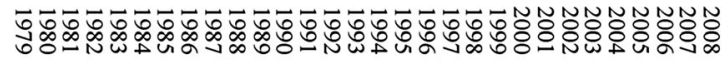

Year

(b)

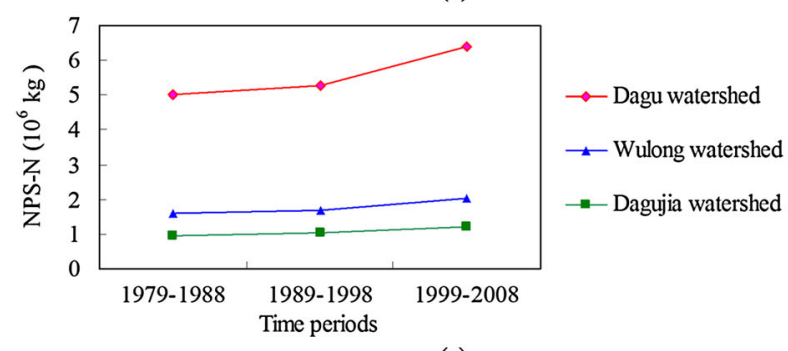

(c)

Figure 3. Temporal changes of NPS-N yield in Jiaodong Peninsula (a) and the three big watersheds $(b, c)$

Table V. NPS-N yield in three 10-year periods in Jiaodong Peninsula

\begin{tabular}{lccc}
\hline Time range & 1979-1988 & 1989-1998 & 1999-2008 \\
\hline $\begin{array}{l}\text { Average annual } \\
\text { NPS-N loads, } 10^{6} \mathrm{~kg}\end{array}$ & 18.69 & 19.64 & 23.16 \\
$\begin{array}{l}\text { Per unit area average } \\
\text { annual NPS-N loads, } \\
\mathrm{kg} \cdot \mathrm{hm}^{-2} \cdot \mathrm{a}^{-1}\end{array}$ & 6.69 & 7.04 & 8.29 \\
\hline
\end{tabular}

watershed had the highest NPS-N yield among the three watersheds, with an annual average yield of $5.50 \times 10^{6} \mathrm{~kg}$. Estimated annual average NPS-N yield in Wulong watershed and Dagujia watershed were $1.81 \times 10^{6} \mathrm{~kg}$ and $1.07 \times 10^{6} \mathrm{~kg}$, respectively. The per unit area NPS-N yield in Dagu watershed, Wulong watershed, and Dagujia watershed were $9.05 \mathrm{~kg} \cdot \mathrm{hm}^{-2} \cdot \mathrm{a}^{-1}, 6.37 \mathrm{~kg} \cdot \mathrm{hm}^{-1} \cdot \mathrm{a}^{-1}$,

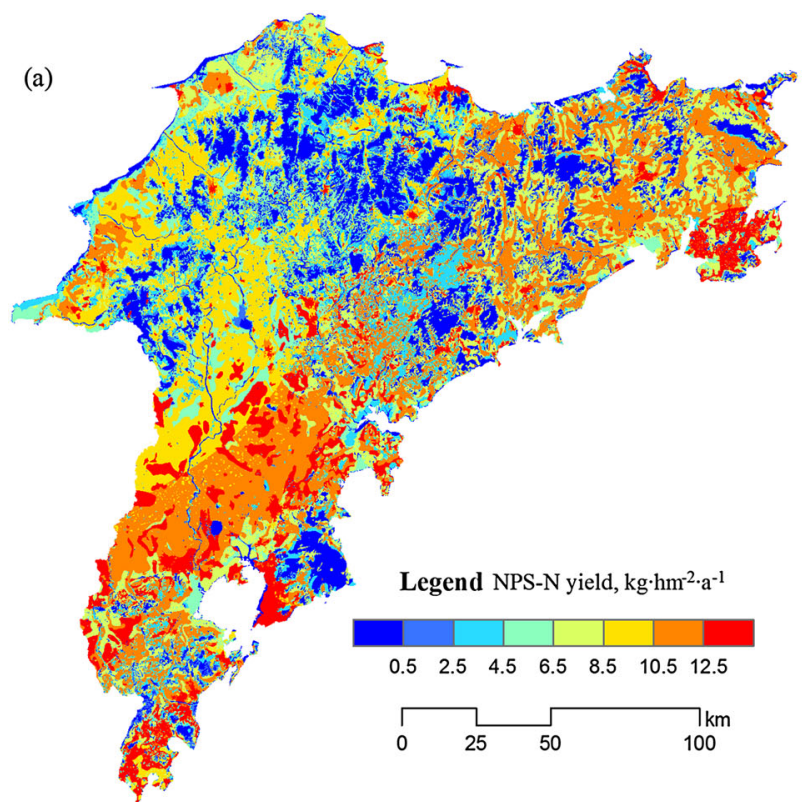

(b)
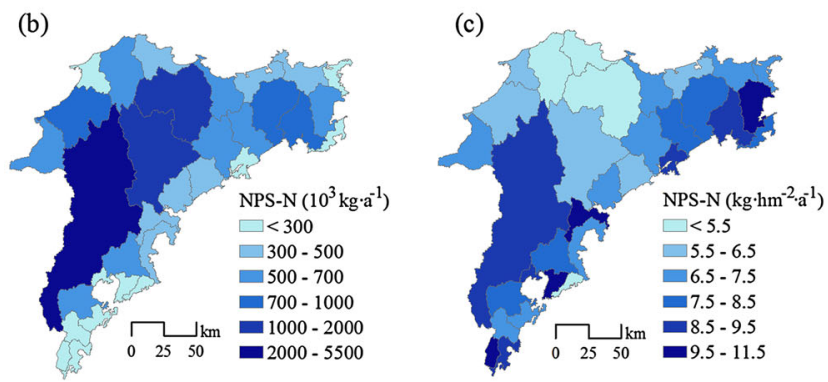

Figure 4. Spatial patterns of NPS-N yield from 1979 to 2008: average annual yield at pixel scale (a) and watershed scale (b), and per unit area average annual yield at watershed scale (c), respectively

and $4.69 \mathrm{~kg} \cdot \mathrm{hm}^{-2} \cdot \mathrm{a}^{-1}$, respectively. On decadal scale, the increase trend of NPS-N yield in all of the three watersheds was apparent (Figure 3-c). Differences in terms of agricultural intensification among the three largest watersheds determines the differences of NPS-N yield; in detail, Dagu watershed possess more preferable agricultural resource and therefore possess higher agricultural intensification than Wulong watershed and Dagujia watershed. Consequently, the most severe environmental impacts of land use are founded in Dagu watershed.

\section{Spatial patterns of NPS-N yield}

The average annual NPS-N yield for the 30 years was estimated and classified into eight levels for each grid cell over the Jiaodong Peninsula, which were $<0.5,0.5-2.5$, $2.5-4.5,4.5-6.5,6.5-8.5,8.5-10.5,10.5-12.5$, and $>12.5 \mathrm{~kg} \cdot \mathrm{hm}^{-2} \cdot \mathrm{a}^{-1}$ respectively (Figure $4-\mathrm{a}$ ). The per unit area annual average yield of the entire peninsula was $7.37 \mathrm{~kg} \cdot \mathrm{hm}^{-2} \cdot \mathrm{a}^{-1}$. It was the main characters of the spatial pattern that the lower the altitude and the nearer to 
the sea, the higher the NPS-N yield. Low NPS-N yield was mainly found in high-altitude mountain regions where vegetation coverage (mainly forest, shrubbery and grassland) is intact. The area proportions of the three levels with higher NPS-N yield $(8.5-10.5,10.5-12.5$, and $>12.5 \mathrm{~kg} \cdot \mathrm{hm}^{-2} \cdot \mathrm{a}^{-1}$ ) amounted to $14.88 \%, 22.07 \%$ and $9.52 \%$ respectively, and approximately $46.47 \%$ in total. These areas were mainly piedmont plains and valleys that widely distributed in coastal zones and low-altitude areas of Jiaodong Peninsula. The highest NPS-N yield mainly distributed in the southern and eastern, as well as urbanized coastal areas in Jiaodong Peninsula.

Average annual NPS-N yield (Figure 4-b) and its per unit area value (Figure 4-c) in each river basin in the past 30 years showed remarkable spatial differences among the river basins. For annual average yield, watershed size

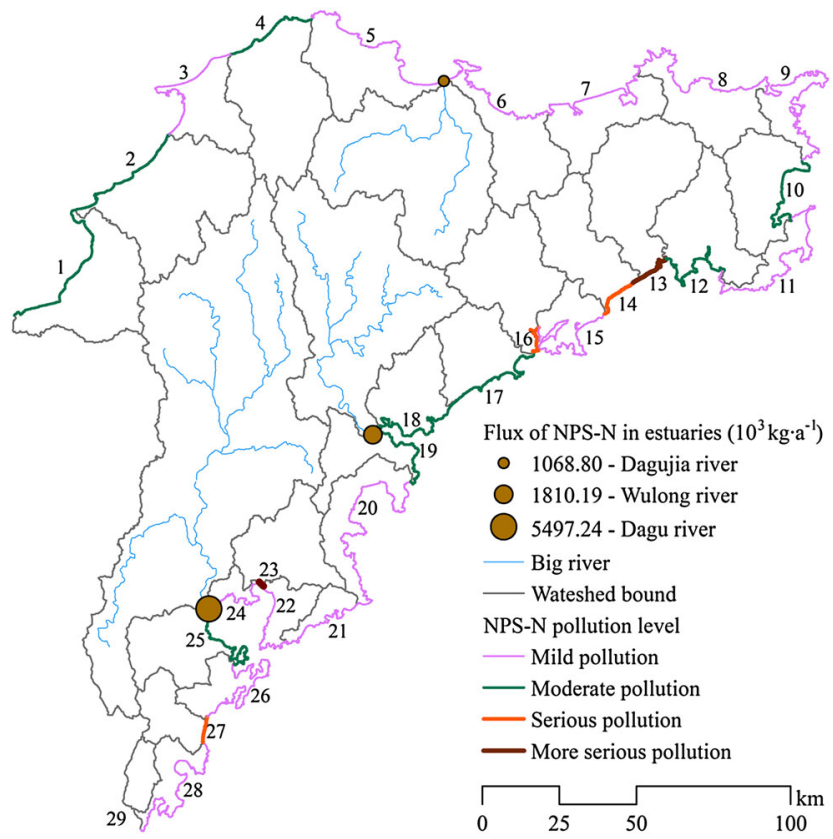

Figure 5. Spatial patterns of NPS-N flux to coastal waters through estuaries and shoreline segments determined the spatial patterns of NPS-N yield in Jiaodong Peninsula, the larger the river basin, the higher the NPS-N yield. Among the 32 watersheds, the three largest watersheds had the highest average annual yields. For per unit area value of average annual yield, high yields were mostly found in the east and south part of the peninsula.

\section{NPS-N flux to coastal waters through estuaries and shoreline segments}

We divided the 32 watersheds into two groups according to their hydrological characters, one was the three largest watersheds that still have perennial runoff regimes, and the other was the 29 mesoscale and smallscale watersheds that were characterized by intermittent runoff (storm-water runoff mainly) in recent decades. Then, in the three largest watersheds, we defined the estuary flux of NPS-N as the basin-wide overall yields of NPS-N $\left(\mathrm{kg} \cdot \mathrm{a}^{-1}\right)$. While in the 29 mesoscale and smallscale watersheds, we defined the flux of NPS-N as amounts of NPS-N that flows into coastal waters through shoreline along with the storm-water runoff, which was calculated approximatively as the basin-wide overall yields of NPS-N divided by the shoreline length $\left(\mathrm{kg} \cdot \mathrm{km}^{-1} \cdot \mathrm{a}^{-1}\right)$. Therefore, the average annual NPS-N fluxes to coastal waters of the 32 watersheds were ranked (Figure 5). As expected, NPS-N flux was positively associated with watershed size. The average annual NPS-N flux through shoreline segments of the 29 mesoscale and small-scale watersheds was further divided into four levels (Table VI). It shows that, most shoreline segments had mild and moderate pollution levels, while only a few shoreline segments had serious and more serious pollution levels. In specific, 14 segments whose length totally amount to $1458.35 \mathrm{~km}$ had mild pollution level, nine segments whose length totally amount to $557.08 \mathrm{~km}$ had moderate pollution level, three segments whose length totally amount to $49.80 \mathrm{~km}$ had serious pollution level and the three segments whose length totally amount to $25.12 \mathrm{~km}$ had more serious pollution level.

Table VI. Ranks of NPS-N flux to coastal waters through shoreline segments in Jiaodong Peninsula

\begin{tabular}{|c|c|c|c|c|c|c|}
\hline \multirow{3}{*}{$\begin{array}{l}\text { Ranks of NPS-N } \\
\text { pollution }\end{array}$} & \multirow[b]{2}{*}{ NPS-N flux } & \multicolumn{3}{|c|}{ Shoreline segments } & \multirow{3}{*}{$\begin{array}{c}\begin{array}{c}\text { Total area } \\
\text { of upstream } \\
\text { source area }\end{array} \\
\mathrm{km}^{2}\end{array}$} & \multirow{3}{*}{$\begin{array}{l}\text { Ratio of watershed } \\
\text { area to shoreline } \\
\text { length }\left(\mathrm{R}_{\mathrm{W} / \mathrm{S}}\right)\end{array}$} \\
\hline & & \multirow{2}{*}{ Amounts } & Total length & Length ratio & & \\
\hline & $10^{3} \mathrm{~kg} \cdot \mathrm{km}^{-1} \cdot \mathrm{a}^{-1}$ & & $\mathrm{~km}$ & $\%$ & & \\
\hline Mid pollution & $<5$ & 14 & 1458.35 & 69.77 & 5152.42 & 3.53 \\
\hline Moderate pollution & $5-20$ & 9 & 557.08 & 26.65 & 7107.61 & 12.76 \\
\hline Serious pollution & $20-40$ & 3 & 49.80 & 2.38 & 2075.15 & 41.67 \\
\hline More serious pollution & $>40$ & 3 & 25.12 & 1.20 & 2089.83 & 83.20 \\
\hline Summary & - & 29 & 2090.34 & 100.00 & 16425.01 & 7.86 \\
\hline
\end{tabular}


The ratio of watershed area to shoreline length $\left(\mathrm{R}_{\mathrm{W} / \mathrm{S}}\right)$ is a very basic shape index of coastal watershed. It depicts the extensity of the up-stream area for a certain shoreline segment. Average value of $\mathrm{R}_{\mathrm{W} / \mathrm{S}}$ in watersheds with the same NPS-N pollution level has been calculated (Table VI). It shows that the larger the $\mathrm{R}_{\mathrm{W} / \mathrm{s}}$, the higher the NPS-N pollution levels. The scatter plots of NPS-N flux against $\mathrm{R}_{\mathrm{W} / \mathrm{s}}$ for the 29 watersheds individually (Figure 6) further confirm a strong linear (positive correlation) relationship between these two variables. This character proves that the extensity of the up-stream area for a certain shoreline segment has very significant impacts on the levels of land-based diffuse pollution in the shoreline's adjacent coastal waters. We infer that, most probably, the rule revealed by these results is universally valid if there are limited differences of physical conditions and social-economic status among the up-stream area of different shoreline segments. At the same time, we think that more case studies are necessary to test the rule.

\section{Levels of land-based NPS-N pollution in different sea areas}

The coastal waters around Jiaodong Peninsula are spatially divided into four sea areas, including Bohai Bay,

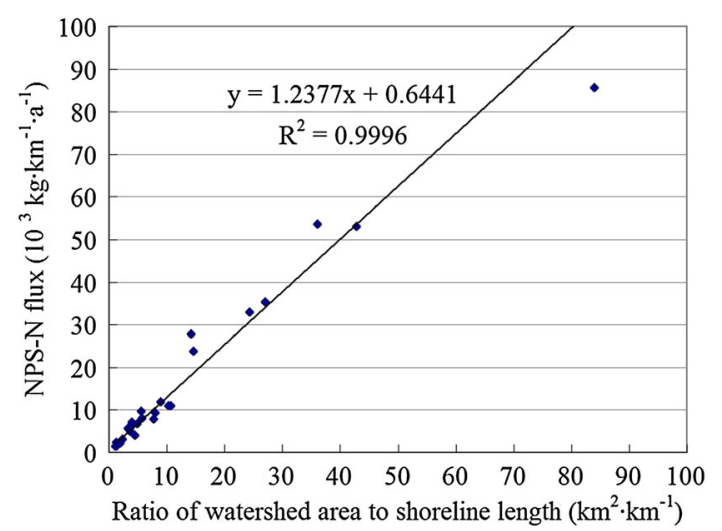

Figure 6. Scatter plots of NPS-N flux and Ratio of watershed area to shoreline length
North-Yellow Sea, Jiaozhou Bay and South-Yellow Sea. Total NPS-N yields in their adjacent coastal watersheds had been summed up (Table VII), which depict the status of the land-based NPS-N pollutions in the four sea areas. It shows that, Bohai Bay had the lowest average annual loads of land-based NPS-N, but its land-based NPS-N load per unit area was higher than that in North-Yellow Sea. South-Yellow Sea had the largest average annual loads of land-based NPS-N, but its land-based NPS-N load per unit area was lower than that in Jiaozhou Bay. Overall, among the four sea areas adjacent to Jiaodong Peninsula, Jiaozhou Bay was the most noteworthy area not only because it had very serious land-based NPS-N pollution, but also because it was a nearly enclosed sea.

\section{Effects of land use structures on land-based NPS-N pollution of coastal waters}

Land use structures had strong impacts on NPS-N pollution. Generally, watersheds with high proportions of farmland, rural settlement and urban built-up area had higher NPS-N yields, while watersheds with high proportions of forest and grassland had lower NPS-N yields. Jiaodong Peninsula has been one of the few areas in China with a high productivity in fruit and grains, and with a widespread distribution of farmland and orchard. The results of this study confirm that the spatial patterns of land use had significant impacts on watershed NPS-N yield and land-based NPS pollutions of coastal waters in Jiaodong Peninsula. Farmland accounts for 34.03\%, $49.47 \%$ and $73.68 \%$ of the total area in Dagujia river basin, Wulong river basin and Dagu river basin, respectively. Accordingly, among the three river basins, Dagu river basin had the highest average annual NPS-N yield while the Dagujia river basin had the lowest (Figure 7-a). Furthermore, variation of land use structure among the 32 watersheds was one of the key control factors of the inconsistency between spatial patterns of NPS-N yield (Figure 4-b) and that of per unit area NPS-N yield (Figure 4-c). Among the four levels of NPS-N flux through the 29 shoreline segments (Figure 5, Figure 7-b), the NPS-N pollution levels and land use structure in its

Table VII. Levels of land-based NPS-N pollution in different sea areas around Jiaodong Peninsula

\begin{tabular}{|c|c|c|c|c|c|}
\hline Sea area & $\begin{array}{l}\text { Shoreline segment, } \\
\text { estuary }\end{array}$ & $\begin{array}{l}\text { Shoreline length, } \\
\mathrm{km}\end{array}$ & $\begin{array}{c}\text { Catchment area, } \\
\mathrm{km}^{2}\end{array}$ & $\begin{array}{c}\text { Load of land-based } \\
\text { NPS-N, } \\
10^{3} \mathrm{~kg} \cdot \mathrm{a}^{-1}\end{array}$ & $\begin{array}{l}\text { Land-based NPS-N } \\
\text { load per unit area, } \\
\mathrm{kg} \cdot \mathrm{km}^{-2} \cdot \mathrm{a}^{-1}\end{array}$ \\
\hline Bohai bay & $1-4$ & 256.60 & 3943.08 & 2385.46 & 604.97 \\
\hline $\begin{array}{l}\text { North-yellow } \\
\text { Sea }\end{array}$ & 5-9, Dagujia estuary & 571.99 & 5075.50 & 2915.00 & 574.33 \\
\hline $\begin{array}{l}\text { South-yellow } \\
\text { Sea }\end{array}$ & $\begin{array}{l}\text { 10-21, 26-29, Wulong } \\
\text { estuary }\end{array}$ & 1089.53 & 10864.61 & 8111.48 & 746.60 \\
\hline Jiaozhou bay & 22-25, Dagu estuary & 172.22 & 7730.50 & 6939.04 & 897.62 \\
\hline
\end{tabular}


(a)

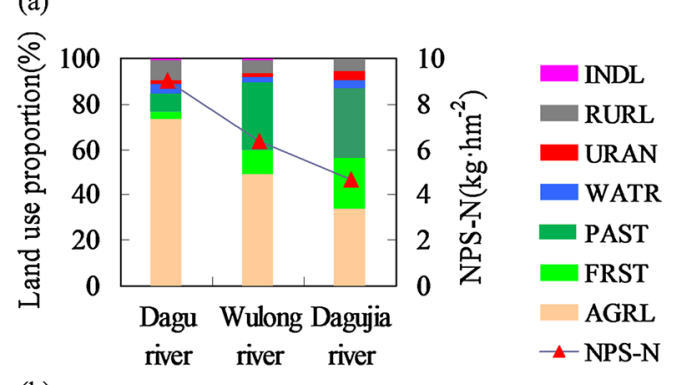

(b)

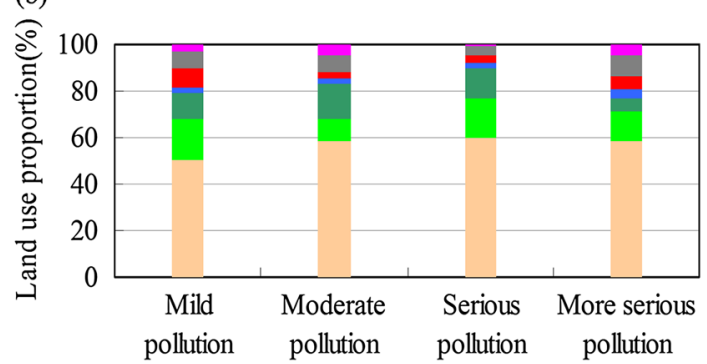

Figure 7. Correlations between land use structures and NPS-N pollution

watershed area were strongly correlated. Low proportion of farmland and high proportion of forest- grassland had mild pollution, high proportion of farmland and low proportion of forest-grassland had moderate pollution, highest proportion of farmland had serious pollution, while lowest proportion of forest-grassland and highest proportion of rural settlements had extreme serious pollution.

Moreover, data in some watersheds do confirm that more intensive watershed land use activities, mainly characterized by much higher proportion of built-up area and much lower proportion of forest-grassland had boosted the NPS-N pollution levels. For example, in the case of shoreline segment 13 and 16 whose $\mathrm{R}_{\mathrm{W} / \mathrm{S}}$ was 53.11 and 53.67, respectively, the NPS-N pollution level ranked 'More serious pollution' and 'Serious pollution', respectively (Figure 5), which were inconsistent with the liner (positive correlation) relationship between NPS-N flux and $\mathrm{R}_{\mathrm{W} / \mathrm{S}}$ (Figure 6). This inconsistency was mainly ascribed to the irrational land use activities in watershed area of shoreline segment 13. In detail, the proportion of farmland in watershed area of shoreline segment 13 was far more than that of shoreline segment 16, while the proportions of forest and grassland in the former were far less than that of the latter.

\section{CONCLUSIONS}

In this study, NPS-N pollution in Jiaodong Peninsula, China from 1979 to 2008 was estimated at $100 \mathrm{~m}$ spatial scale based on multi-source database and using spatial analysis techniques, SCS-CN method and pollutant coefficient method. The main conclusions are as follows:.
(1) The average annual NPS-N yield was about $20.35 \times 10^{6} \mathrm{~kg} \cdot \mathrm{a}^{-1}$ in the past 30 years in Jiaodong Peninsula. The annual yield exhibited a strong interannual variation and an increasing trend on a decadal scale. Overall, peninsula's mountainous regions with high vegetation cover had low NPS-N yields, while southern and eastern parts of the Peninsula, as well as urbanized coastal areas, contributed to most of the NPS-N yields.

(2) At the watershed scale, spatial patterns of total NPS-N yield were mainly determined by the watershed size. Larger river basins usually have a higher total NPS-N yield. However, per unit area NPS-N yield in each watershed showed a more complicated spatial pattern because land use structures become one of the main impact factors. Watersheds with high proportions of farmland and urbanized areas and low proportions of forest and grassland were characterized by much higher NPS-N yield in Jiaodong Peninsula.

(3) Large river basins usually have large NPS-N fluxes to estuaries. The NPS-N flux from land to coastal waters through shoreline segments in the 29 mesoscale and small-scale watersheds exhibited complicated spatial patterns and temporal variations. The ratio of watershed area to shoreline length $\left(\mathrm{R}_{\mathrm{W} / \mathrm{S}}\right)$ was a fundamental controlling factor of the shoreline NPS-N flux. In large-scale coastal areas lack of observed water quality data, the rule revealed by the scatter plots of NPS-N flux against $\mathrm{R}_{\mathrm{W} / \mathrm{s}}$ will support us to find coastal waters with high-risk levels of land-based NPS pollutions. Furthermore, land use structure affected or modified the levels and spatial patterns of shoreline NPS-N flux. Watersheds with intense land use tend to yield large NPS-N fluxes.

The implications or inspirations from this study are as follows. (1) Watershed- or river-basin-based evaluations on long-term NPS pollution in coastal areas are critical for both LOICZ studies and ICZM practices because differences of NPS pollution and their controlling factors among watersheds are very significant. As a result, the combination between ICZM and integrated river basin management (IRBM) in coastal zone is highly recommended. (2) NPS pollutants fluxes through shoreline into coastal waters in mesoscale and small-scale coastal watersheds with seasonal rivers are mainly affected by storm water pollutions. Furthermore, watersheds with a high $\mathrm{R}_{\mathrm{W} / \mathrm{S}}$ (ratio of watershed area to shoreline length) should be paid more attentions in terms of hydrological and environmental monitoring and IRBM practices. (3) The main source areas of NPS pollutants should be taken as the key targets of 'pollution source control practices', and on the other hand, watershed land use planning and landscape designing should be considered as primary approaches of prevention and mitigation of water pollutions in coastal zones. 


\section{ACKNOWLEDGEMENTS}

This study was supported by the National Natural Science Foundation of China (Grant No. 40801016, 40901028) and the Knowledge Innovation Program of the Chinese Academy of Sciences (Grant No. kzcx2-yw-224). We are grateful to the reviewers for their helpful comments and suggestions.

\section{REFERENCES}

Badruzzaman M, Pinzon J, Oppenheimer J, Jacangelo JG. 2012. Sources of nutrients impacting surface waters in Florida: A review. Journal of Environmental Management 109: 80-92.

Bao QS, Cao LJ, Wang HD. 1997. Study on non-point source pollution loading of the Miyun Reservoir. Water Resource Protection 66: 8-11. (in Chinese)

Blanco AC, Nadaoka K, Yamamoto T, Kinjo K. 2010. Dynamic evolution of nutrient discharge under stormflow and baseflow conditions in a coastal agricultural watershed in Ishigaki Island, Okinawa, Japan. Hydrological Processes 24: 2601-2616.

Bradley DE, David P. 2003. Intra- and inter-annual variability in the different forms of diffuse nitrogen and phosphorus delivered to seven sub-tropical east Australian estuaries. Estuarine, Coastal and Shelf Science 57: 137-148.

Chen DJ, Lu J, Wang HL, Shen YN, Gong DQ. 2011. Combined inverse modeling approach and load duration curve method for variable nitrogen total maximum daily load development in an agricultural watershed. Environmental Science and Pollution Research 18: 1405-1413.

Dowd BM, Press D, Huertos ML. 2008. Agricultural nonpoint source water pollution policy: The case of California's central coast. Agriculture, Ecosystems and Environment 128: 151-161.

Goolsby DA, Battaglin WA. 2001. Long-term changes in concentrations and flux of nitrogen in the Mississippi River Basin, USA. Hydrological Processes 15: 1209-1226.

Guo HY, Wang XR, Zhu JG. 2004. Quantification and index of non-point source pollution in Taihu Lake region with GIS. Environmental Geochemistry and Health 26: 147-156.

Han HY, Li KQ, Wang XL, Shi XY, Qiao XD, Liu J. 2011. Environmental capacity of nitrogen and phosphorus pollutions in Jiaozhou Bay, China: Modeling and assessing. Marine Pollution Bulletin 63: 262-266.

Hao YJ, Tang DL, Yu L, Xing QG. 2011. Nutrient and chlorophyll a anomaly in red-tide periods of 2003-2008 in Sishili Bay, China. Chinese Journal of Oceanology and Limnology 29: 664-673.

Houk P, Didonato G, Iguel J, Woesik RV. 2005. Assessing the effects of non-point source pollution on American Samoa's coral reef communities. Environmental Monitoring and Assessment 107: 11-27.

Howarth RW. 2008. Coastal nitrogen pollution: A review of sources and trends globally and regionally. Harmful Algae 8: 14-20.

Huang JL, Hong HS. 2010. Comparative study of two models to simulate diffuse nitrogen and phosphorus pollution in a medium-sized watershed, southeast China. Estuarine, Coastal and Shelf Science 86: 387-394.

Huang JL, Hong HS, Zhang LP, Du PF. 2004. Nitrogen and phosphorus loading of agricultural non-point sources in Jiulong river watershed based on GIS. Journal of Agro-Environment Science 23: 866-871. (in Chinese)

Huang JL, Hong HS, Du PF, Zhang LP. 2005. Testing AnnAGNPS for water quality modelling in the typical sub-watersheds in Jiulong River watershed. Acta Scientiae Circumstantiae 25: 1135-1142. (in Chinese)

Islam MS, Tanaka M. 2004. Impacts of pollution on coastal and marine ecosystems including coastal and marine fisheries and approach for management: a review and synthesis. Marine Pollution Bulletin 48: 624-649.

Kuang C, Neumann T, Norra S, Stüben D. 2004. Land use-related chemical composition of street sediments in Beijing. Environmental Science and Pollution Research 11: 73-83.
Lee JA, Gill TE, Mulligan KR, Acosta MD, Perez AE. 2009. Land use/ land cover and point sources of the 15 December 2003 dust storm in southwestern North America. Geomorphology 105: 18-27.

Li HP, Liu XM, Huang WY. 2004. The non-point output of different land use types in Zhexi hydraulic region of Taihu basin. Acta Geographica Sinica 59: 401-408. (in Chinese)

Li HP, Huang WY, Yang GS, Liu XM. 2006a. Non-point pollutant concentrations for different land uses in Lihe river watershed of Taihu region. China Environmental Science 26: 243-247. (in Chinese)

Li HP, Yang GS, Huang WY, Yu XX, Liang T, Li ZF. 2006 b. Comparison of nitrogen and phosphorus concentration of runoff from different spatial scale watersheds. Journal of Lake Sciences 18: 377-386. (in Chinese)

Li HP, Yang GS, Li Y. 2006c. Simulation of nutrient fluxes response of land use change in Taihu basin. Journal of Soil and Water Conservation 20: 179-182. (in Chinese)

Li ZF, Yang GS, Li HP. 2007. Estimation of nutrient export coefficient from different land use types in Xitiaoxi watershed. Journal of Soil and Water Conservation 21: 1-4. (in Chinese)

Li XZ, Mander U, Ma ZG, Jia Y. 2009a. Water quaity problems and potential for wetlands as treatment systems in the Yangze River Delta, China. Wetlands 29: 1125-1132.

Li ZF, Yang GS, Li HP. 2009b. Estimated nutrient export loads based on improved export coefficient model in Xitiaoxi watershed. Environmental Science 30: 668-672. (in Chinese)

Liang CD, Long TY, Li JC, Liu LM. 2007. Importation loads of non-point source nitrogen and phosphorus in the Three Gorges Reservoir. Resources and Environment in the Yangtze Basin 16: 26-30. (in Chinese)

Liu SM, Li XN, Zhang J, Wei H, Ren JL, Zhang GL. 2007. Nutrient Dynamics in Jiaozhou Bay. Water, Air and Soil Pollution: Focus 7: 625-643.

Liu LM, Long TY, Li CM, Li JC. 2009. Simulation of dissolved nitrogen load in Jialing river basin. Journal of Agro-Environment Science 28: 808-813. (in Chinese)

Liu SM, Zhu BD, Zhang J, Wu Y, Liu GS, Deng B, Zhao MX, Liu GQ, Du JZ, Ren JL, Zhang GL. 2010. Environmental change in Jiaozhou Bay recorded by nutrient components in sediments. Marine Pollution Bulletin 60: 1591-1599.

Long TY, Liang CD, Li JC, Liu LM. 2008. Forecasting the pollution load of non-point sources imported to the Three Gorges Reservoir. Acta Scientiae Circumstantiae 28: 574-581. (in Chinese)

Ma X, Li Y, Zhang M, Zheng FZ, Du S. 2011. Assessment and analysis of non-point source nitrogen and phosphorus loads in the Three Gorges Reservoir Area of Hubei province, China. Science of the Total Environment 412: 154-161.

Maxted J, Diebel M, Vander ZM. 2009. Landscape planning for agricultural non-point source pollution reduction. II. Balancing watershed size, number of watersheds, and implementation effort. Environmental Management 43: 60-68.

Meixler MS, Bain MB. 2010. A water quality model for regional stream assessment and conservation strategy development. Environmental Management 45: 868-880.

Miller JD, Schoonover JE, Williard KWJ, Hwang CR. 2011. Whole catchment land cover effects on water quality in the lower Kaskaskia river watershed. Water, Air, and Soil Pollution 221: 337-350.

Mishra SK, Tyagi JV, Singh VP, Singh R. 2006. SCS-CN-based modeling of sediment yield. Journal of Hydrology 324: 301-322.

Moriasi DN, Arnold JG, Van Liew MW, Bingner RL, Harmel RD, Veith TL. 2007. Model evaluation guidelines for systematic quantification of accuracy in watershed simulations. Transactions of the ASABE 50: 885-900.

Nagy RC, Lockaby BG, Kalin L, Anderson C. 2012. Effects of urbanization on stream hydrology and water quality: the Florida Gulf Coast. Hydrological Processes 26: 2019-2030.

Nash JE, Sutcliffe JG. 1970. River flow forecasting through conceptual models: part 1. A discussion of principles. Journal of Hydrology 10: 282-290.

Nikolaidis NP, Heng H, Semagin R, Clausen JC. 1998. Non-linear response of a mixed land use watershed to nitrogen loading. Agriculture, Ecosystems and Environment 67: 251-265.

Norse D. 2005. Non-point pollution from crop production: Global, regional and national issues. Pedosphere 4: 499-508. 
Ongley ED, Zhang XL, Yu T. 2010. Current status of agricultural and rural non-point source Pollution assessment in China. Environmental Pollution 158: 1159-1168.

Pierobon E, Castaldelli G, Mantovani S, Vincenzi F, Fano EA. 2012. Nitrogen removal in vegetated and unvegetated drainage ditches impacted by diffuse and point sources of pollution. CLEAN - Soil, Air, Water. DOI: 10.1002/clen.201100106.

Rollo N, Robin M. 2010. Relevance of watershed modelling to assess the contamination of coastal waters due to land-based sources and activities. Estuarine, Coastal and Shelf Science 86: 518-525.

Santhi C, Arnold JG, Williams JR, Dugas WA, Srinivasan R, Hauck LM. 2001. Validation of tbe SWAT model on a large river basin with point and nonpoint sources. Journal of the American Water Resources Association 37: 1169-1188.

Schreiber JD, Rebich RA, Cooper CM. 2001. Dynamics of diffusion pollution from US southern watersheds. Water Research 10: 2534-2542.

Selig U, Baudler H, Krech M, Nausch G. 2006. Nutrient accumulation and nutrient retention in coastal waters - 30 years investigation in the DarssZingst Bodden chain. Acta hydrochimica et hydrobiologica 34: 9-19.

Shamshad A, Leow CS, Ramlah A, Hussin W, Sanusi SAM. 2008. Applications of AnnAGNPS model for soil loss estimation and nutrient loading for Malaysian conditions. International Journal of Applied Earth Observation and Geoinformation 10: 239-252.

Shen ZY, Liao Q, Hong Q, Gong YW. 2012. An overview of research on agricultural non-point source pollution modelling in China. Separation and Purification Technology 84: 104-111.

Ulen B, Bechmann M, Fölster J, Jarvie HP, Tunney H. 2007. Agriculture as a phosphorus source for eutrophication in the north-west European countries, Norway, Sweden, United Kingdom and Ireland: a review. Soil Use and Management 23(Suppl. 1): 5-15.

Van Liew MW, Arnold JG, Garbrecht JD. 2003. Hydrologic simulation on agriculture watersheds: Choosing between two models. Transactions of ASAE 46: 1539-1551.

Wang XY, Wang YX, Li TF, He W, Hu QJ, Zhang HF. 2002. Characteristics of non-point source pollution in the watershed of Miyun Reservoir, Beijing, China. Chinese Journal of Geochemistry 21: 89-96.

Wang XY, Guo F, Cai XG, Hu QJ. 2003. Non-point source pollution loading of Miyun reservoir, Beijing. Urban Environment \& Urban Ecology 16: 31-33. (in Chinese)

Wang XY, Wang XF, Wang QP, Wang ZG, Cai XG. 2004. Loss of nonpoint source pollutants from Shixia small watershed, Miyun reservoir, Beijing. Scientia Geographica Sinica 24: 227-231. (in Chinese)
Wei GF, Tang DL, Wang SF. 2008. Distribution of chlorophyll and harmful algal blooms (HABs): A review on space based studies in the coastal environments of Chinese marginal seas. Advances in Space Research 41: 12-19.

Williams R, Keller V, Voß A, Bärlund I, Malve O, Riihimäki J, Tattari S, Alcamo J. 2012. Assessment of current water pollution loads in Europe: estimation of gridded loads for use in global water quality models. Hydrological Processes 26: 2395-2410.

Wit RD, Leibreich J, Vernier F, Delmas F, Beuffe H, Maison P, Chossat JC, Laplace-Treyture C, Laplana R, Clave V, Torre M, Auby I, Trut G, Maurer D, Capdeville P. 2005. Relationship between land-use in the agro-forestry system of les Landes, nitrogen loading to and risk of macro-algal blooming in the Bassin d'Arcachon coastal lagoon (SW France). Estuarine, Coastal and Shelf Science 62: 453-465.

Wu L, Long TY, Cooper WJ. 2012. Temporal and spatial simulation of adsorbed nitrogen and phosphorus nonpoint source pollution load in Xiaojiang watershed of Three Gorges Reservoir Area, China. Environmental Engineering Science 29: 238-247.

Xiao B, Wang QH, Fan J, Han FP, Dai QH. 2011. Application of the SCSCN Model to Runoff Estimation in a Small Watershed with High Spatial Heterogeneity. Pedosphere 21: 738-749.

Xu K, Wang YP, Su H, Yang JX, Li LL, Liu C. 2012. Effect of land-use changes on nonpoint source pollution in the Xizhi River watershed, Guangdong, China. Hydrological Processes. DOI: 10.1002/hyp.9368.

Yen CH, Chen KF, Sheu YT, Lin CC, Horng JJ. 2012. Pollution source investigation and water quality management in the Carp Lake watershed, Taiwan. CLEAN - Soil, Air, Water 40: 24-33.

Ying LL, Hou XY, Lu X, Zhu MM. 2010. Discussion on the export coefficient method in non-point source pollution studies in China. Journal of Water Resources \& Water Engineering 21: 90-95. (in Chinese)

Yuan D, Lin B, Falconer RA, Tao J. 2007. Development of an integrated model for assessing the impact of diffuse and point source pollution on coastal waters. Environmental Modelling \& Software 22: 871-879.

Zhang J. 2007. Watersheds nutrient loss and eutrophication of the marine recipients: A case study of the Jiaozhou Bay, China. Water, Air and Soil Pollution: Focus 7: 583-592.

Zou GH, Cui JY, Liu ZL, Sun L. 2008. Simulating non-point pollution at watershed scale: A case study in Dagu watershed. Resources Science 30: 288-295. (in Chinese) 